\title{
Pengelolaan Konsumsi Air Bersih pada Rumah Tangga di Kecamatan Peudada Kabupaten Bireun
}

\author{
Zulhilmi $^{1}$, Idawati $^{2}$ \\ ${ }^{1}$ Mahasiswa Kebijakan dan Manajemen Pelayanan Kesehatan S2 IKM Institut Kesehatan Helvetia, \\ Medan \\ ${ }^{2}$ STIKes Medika Nurul Islam Sigli \\ Email : hilmipanglima5@gmail.com \\ Email : idawati.medika@gmail.com \\ DOI : 10.32672/jsa.v7i5.1523
}

\begin{abstract}
Clean water is one of the important needs in human life and a natural resource that has a very vital function. A preliminary study conducted in Peudada Subdistrict by visiting 20 community houses in several villages found that the community was increasingly aware of the importance of clean water, which led to increased demand for clean water. The purpose of the study was to analyze the factors that influence the level of implementation of management of clean water consumption in households in Peudada Subdistrict, Bireuen District in 2019. This type of research is a quantitative study conducted by analytic survey with cross sectional approach. The population is the number of all adolescents as many as 4,892 families, using the sample solvin formula in this study 98 families. The results showed that there was a relationship between family income and water consumption, with a probability value (0.029) <sig_ $\alpha=0.05$, there was a relationship between the number of family members with water consumption, with a probability value $(0.019)<\operatorname{sig} \_\alpha=0.05$, there was a relationship family members with water consumption, with a probability value $(0,000)<\operatorname{sig} \_\alpha=0.05$, there is a relationship between other clean water sources and water consumption, with a probability value (0.019) $<$ sig_ $\alpha=0.05$ and the dominant clean water quality variable influences management clean water consumption because it has an EXP value (B) with an overall value of percentage $=64.3 \%$.

Keyword : Management of Clean Water Consumption, Households
\end{abstract}

\begin{abstract}
ABSTRAK
Air bersih merupakan salah satu kebutuhan penting dalam kehidupan manusia dan menjadi sumber daya alam yang memiliki fungsi sangat vital. Studi pendahuluan yang dilakukan di Kecamatan Peudada dengan mendatangi 20 rumah masyarakat di beberapa desa menemukan hasil bahwa masyarakat semakin sadar dengan pentingnya air bersih sehingga menyebabkan meningkatnya permintaan ait bersih. Tujuan penelitian untuk menganalisis faktor yang memengaruhi tingkat penerapan pengelolaan konsumsi air bersih pada rumah tangga di Kecamatan Peudada Kabupaten Bireuen tahun 2019. Jenis
\end{abstract}


Zulhilmi, Idawati

penelitian ini merupakan penelitian kuantitatif yang dilakukan secara survey analitik dengan pendekatan crosssectional. Populasi adalah jumlah seluruh remaja sebanyak $4.892 \mathrm{KK}$, dengan menggunakan rumus solvin sampel dalam penelitian ini $98 \mathrm{KK}$. Hasil penelitian menunjukkan bahwa ada hubungan pendapatan keluarga dengan konsumsi air, dengan nilai probabilitasnya $(0,029)$ $<\operatorname{sig} \alpha=0,05$, ada hubungan jumlah anggota keluarga dengan konsumsi air, dengan nilai probabilitasnya $(0,019)<\operatorname{sig} \alpha=0,05$, ada hubungan jumlah anggota keluarga dengan konsumsi air, dengan nilai probabilitasnya $(0,000)<\operatorname{sig} \_\alpha=0,05$, ada hubungan sumber air bersih lain dengan konsumsi air, dengan nilai probabilitasnya $(0,019)<\operatorname{sig} \alpha \alpha=0,05$ dan variabel kualitas air bersih dominan memengaruhi penerapan pengelolaan konsumsi air bersih karena memiliki nilai EXP (B) dengan nilai Overall percentage $=64,3 \%$

Kata Kunci : Pengelolaan Konsumsi Air Bersih, Rumah Tangga

\section{PENDAHULUAN}

Air bersih merupakan salah satu kebutuhan penting dalam kehidupan manusia dan menjadi sumber daya alam yang memiliki fungsi sangat vital. Air bersih digunakan manusia untuk keperluan sehari-hari mulai dari minum, mandi, memasak, mencuci, serta keperluan lainnya. Berdasarkan Peraturan Menteri Pekerjaan Umum dan Perumahan Rakyat Nomor 09/PRT/M/2015 tentang penggunaan sumber air menyebutkan bahwa air adalah semua air yang terdapat didalam dan atau berasal dari sumber-sumber air, baik yang terdapat diatas maupun dibawah permukaan tanah (Apriani, 2018).

Keputusan Menteri Kesehatan Republik Indonesia nomor 1405/MenKes/sk/xi/2002 tentang Persyaratan Kesehatan Lingkungan Kerja Perkantoran dan Industri memuat pengertian tentang air bersih yaitu air yang digunakan untuk keperluan sehari-hari dan kualitasnya memenuhi persyaratan kesehatan air bersih sesuai dengan peraturan perundang-undangan yang berlaku dan dapat diminum apabila dimasak (Hariyadi \& Ekayanti, 2012).

Air juga sangat berperan di dalam upaya untuk meningkatkan kesejahteraan serta kemakmuran masyarakat, sebagaimana ditetapkan dalam pasal 33 ayat 3 UUD 1945 yang berbunyi: "Bumi dan air kekayaan alam yang terkandung didalamnya dikuasai oleh negara dan dipergunakan untuk sebesar-besarnya kemakmuran rakyat". Derajat kesehatan masyarakat di suatu daerah dipengaruhi oleh kondisi lingkungan fisik dan sosial budaya masyarakat. Permasalahan lingkungan yang sering dijumpai dalam kehidupan masyarakat adalah air. Air merupakan salah satu komponen pembentuk lingkungan sehingga tersedianya air yang berkualitas mengindikasikan lingkungan yang baik (Hartono, Sari, Jannah, \& Anonim, n.d.).

Sebagian besar permukaan bumi tertutup oleh air laut, danau, sungai, es dan salju. Lapisan berupa air di bumi yang membentuk lingkungan hidup disebut sebagai hidrosfer. Hidrosfer mempunyai banyak manfaat bagi semua makhluk hidup termasuk manusia. Sebagian besar tubuh manusia dan organ tubuhnya terdiri dari air, sehingga air sesungguhnya adalah kehidupan. Air yang dapat dimanfaatkan oleh manusia adalah air presipitasi atau hujan, air limpasan, air tanah dan juga berkat dukungan teknologi yaitu air laut. Reservoir utama di daratan adalah sungai, danau dan air tanah. Dari sumber inilah air 
digunakan untuk irigasi, industri dan untuk keperluan rumah tangga. Sumber air bersih didapat dari membangun jaringan perpipaan untuk dapat menampung air sungai atau mata air yang diolah lebih lanjut untuk siap disalurkan ke permukiman dan kawasan industry (Indonesia, 2014).

Jumlah pemakaian serta jenis kebutuhan air setiap orang berbeda-beda tergantung segala aktivitas serta pola hidupnya. Air yang diperlukan manusia harus cukup untuk seluruh kebutuhan hidup khususnya kebutuhan untuk minum. Air dimanfaatkan oleh berbagai sektor ekonomi antara lain sektor rumah tangga, pertanian, industri dan infrastruktur. Pendistribusian air antar daerah berbeda-beda, tergantung bagaimana cara untuk membagi air dari satu sumber air yang terdapat pada suatu daerah ke daerah-daerah di sekitarnya terutama ke daerah kering yang harus segera mendapatkan saluran air (Karolina, Nasution, \& Aritonang, 2013).

Air merupakan sumber daya alam yang dikategorikan sebagai barang publik, dimana keberadaannya berada dibawah campur tangan pemerintah agar dapat diperoleh lokasi dan distribusi yang optimal demi efisiensi dan keadilan. Sedangkan, bangunan air sesuai dengan tujuan dan fungsinya termasuk salah satu dari bangunan sipil. Secara sederhana dapat dikatakan bahwa yang dimaksud dengan bangunan air adalah bangunan sipil untuk memanfaatkan, mengatur, serta mengendalikan air baik dari segi alirannya maupun dari daya yang terkandung didalamnya. Kelompok bangunan air cukup banyak diantaranya yaitu: bangunan sungai, bangunan irigasi, bangunan drainase, bendungan, pelimpah, dan bangunan tenaga air/ PLTA (Kementerian Kesehatan, 2015).

Melihat begitu pentingnya masalah kebutuhan air bagi masyarakat, pemerintah perlu memberikan perhatian khusus dalam masalah pengelolaan air. Pengelolaan air bersih merupakan upaya untuk mendapatkan air yang bersih dan sehat sesuai dengan standar mutu air untuk kesehatan. Tujuan dari sistem penyediaan air bersih adalah menyediakan jumlah air yang cukup untuk kebutuhan masyarakat sesuai dengan tingkat kemajuan dan perkembangan daerah pelayanan. Di Indonesia, pengelolaan serta pendistribusian air bersih dikelola oleh Negara (Pelayanan, Care, Tamamaung, Makassar, \& Kunci, n.d.).

Hasil Riskesdas 2016 menunjukkan bahwa jenis sumber utama air untuk seluruh keperluan rumah tangga pada umumnya menggunakan sumur gali terlindung $(27,9 \%)$ dan sumur bor/pompa $(22,2 \%)$ dan air ledeng/PAM (19,5\%). Berdasarkan karakteristik tempat tinggal, terdapat perbedaan jenis penggunaan sumber utama air untuk keperluan rumah tangga. Di perkotaan, pada umumnya rumah tangga menggunakan sumur bor/pompa $(30,3 \%)$, sedangkan di perdesaan lebih banyak menggunakan sumur gali terlindung (29,6\%) (Moleong, 1999).

Hal ini ditegaskan dalam Peraturan Pemerintah RI 1990 tentang kualitas air, yang menyatakan air sangat penting untuk mempertahankan kelangsungan hidup, maka manusia berupaya memperoleh air yang cukup bagi dirinya. Namun dalam banyak hal air yang digunakan tidak selalu sesuai dengan syarat kesehatan, sering ditemukan air tersebut mengandung bibit penyakit atau zat-zat tertentu yang dapat menimbulkan penyakit yang justru membahayakan kelangsungan hidup manusia (Liana, Soharno, \& Panjaitan, 2018).

Menurut survei awal yang dilakukan peneliti pada bulan Agustus 2018 di Kecamatan Peudada dengan mendatangi 20 rumah masyarakat di beberapa desa yang ada 
Zulhilmi, Idawati

di Kecamatan Peudada menemukan hasil bahwa masyarakatKecamatan Peudada semakin sadar dengan pentingnya air bersih sehingga menyebabkan permintaan akan tersedianya air bersih semakin meningkat. Disamping itu, peningkatan jumlah pendapatan perkapita penduduk dari tahun ke tahun juga menyebabkan permintaan penduduk akan tersedianya air bersih, semakin meningkat pemasangan PDAM disetiap rumah masyarakat ditambah lagi dengan mereka yang memiliki rumah sebagai kos-kosan atau warung. Bertambahnya jumlah pelanggan tidak diikuti dengan jumlah produksi air bersih yang justru semakin menurun dalam kurun waktu 2 tahun terakhir ini. Dari hasil uraian diatas Maka penulis tertarik untuk melakukan penelitian dengan judul "Faktor yang memengaruhi tingkat penerapan pengelolaan konsumsi air bersih pada rumah tangga di Kecamatan Peudada Kabupaten Bireuen tahun 2019.

\section{METODE PENELITIAN}

Jenis penelitian yang digunakan dalam penelitian ini adalah survei analitik dengan desain cross sectional study yang bertujuan untuk menganalisis faktor yang memengaruhi tingkat penerapan pengelolaan konsumsi air bersih pada rumah tangga di Kecamatan Peudada Kabupaten Bireuen tahun 2019 yang diamati pada periode waktu yang sama (Muhammad, 2013).

Populasi dalam penelitian ini adalah seluruh kepala keluarga yang ada di Kecamatan Peudada Kabupaten Bireuen sebanyak 4.892 Kepala Keluarga. Sampel dalam penelitian ini adalah sebagian kepala keluarga yang ada di Kecamatan Peudada Kabupaten Bireuen. Setelah dilakukan perhitungan maka diperoleh jumlah sampel yang akan diteliti adalah sebanyak $98 \mathrm{KK}$ yang diwakili oleh satu orang setiap satu rumah.

\section{HASIL PENELITIAN DAN PEMBAHASAN Analisis Univariat}

Berdasarkan hasil penelitian didapatkan bahwa distribusi frekuensi responden berdasarkan pendapatan keluarga terhadap faktor yang memengaruhi tingkat penerapan pengelolaan konsumsi air bersih pada rumah tangga di Kecamatan Peudada Kabupaten Bireuen yang berpenghasilan < Rp 2.500 .00059 orang $(60,2 \%)$ dan yang berpenghasilan $\geq \operatorname{Rp} 2.500 .00039$ orang $(39,8 \%)$. Distribusi frekuensi responden berdasarkan jumlah anggota keluarga terhadap faktor yang memengaruhi tingkat penerapan pengelolaan konsumsi air bersih pada rumah tangga di Kecamatan Peudada Kabupaten Bireuen yang mempunyai anak $<5$ orang 49 orang $(50 \%)$ dan yang berpenghasilan $\geq 5$ orang 49 orang (50\%). Distribusi frekuensi responden berdasarkan jumlah kualitas air bersih terhadap faktor yang memengaruhi tingkat penerapan pengelolaan konsumsi air bersih pada rumah tangga di Kecamatan Peudada Kabupaten Bireuen yang kualitas air kotor 59 orang $(60,2 \%)$ dan yang kualitas air bersih 39 orang $(39,8 \%)$. Distribusi frekuensi responden berdasarkan distribusi frekuensi responden berdasarkan konsumsi air terhadap faktor yang memengaruhi tingkat penerapan pengelolaan air bersih pada rumah tangga di Kecamatan Peudada Kabupaten Bireuen yang tidak mengkonsumsi 63 orang $(64,3 \%)$ dan yang konsumsi 35 orang $(35,7 \%)$. 
Serambi Akademica

Jurnal Pendidikan, Sains, dan Humaniora
Vol. 7, No. 5,

Oktober 2019
pISSN 2337-8085

eISSN 2657- 0998

\section{Analisis Bivariat}

Analisis bivariat adalah analisis secara simultan dari dua variabel. Hal ini biasanya dilakukan untuk melihat apakah satu variabel berkaitan dengan variabel lain.

Dari hasil penelitian didapatkan bahwa dari 98 responden yang memiliki pendapatan < Rp 2.500.000 59 orang dengan tidak mengkonsumsi air bersih 43 orang $(72,9 \%)$ dan yang konsumsi air bersih 16 orang $(27,15 \%)$ sedangkan yang pendapatan $\geq$ Rp 2.500.000 39 orang dengan tidak mengkonsumsi air bersih 20 orang $(51,3 \%)$ dan mengkonsumsi air bersih 19 orang (48,7\%). Selanjutnya dari hasil analisa pada lampiran tabel uji chi-square antara konsumsi air dengan pendapatan keluarga, diketahui bahwa nilai probabilitasnya $(0,029)<$ sig $\_\alpha=0,05$. Hasil analisis ini memenuhi kriteria persyaratan hipotesis ada hubungan, sehingga dapat disimpulkan bahwa pendapatan keluarga mempunyai hubungan yang signifikan terhadap konsumsi air.

Dari 98 responden yang memiliki jujlah anggota keluarga $<5$ orang 60 orang dengan tidak mengkonsumsi air bersih 44 orang $(73,3 \%)$ dan yang konsumsi air bersih 16 orang $(26,7 \%)$ sedangkan yang anggota keluarga $\geq 5$ orang 39 orang dengan tidak mengkonsumsi air bersih 19 orang (50\%) dan mengkonsumsi air bersih 19 orang (50\%). Selanjutnya dari hasil analisa pada lampiran tabel uji chi-square antara konsumsi air dengan jumlah anggota keluarga, diketahui bahwa nilai probabilitasnya $(0,019)>\operatorname{sig} \_\alpha=0,05$. Hasil analisis ini memenuhi kriteria persyaratan hipotesis ada hubungan, sehingga dapat disimpulkan bahwa jumlah anggota keluarga mempunyai hubungan yang signifikan terhadap konsumsi air.

Dari 98 responden yang memiliki kualitas air kotor 59 orang dengan tidak mengkonsumsi air bersih 59 orang (100\%) dan tidak ada yang mengkonsumsi air bersih sedangkan kualitas air bersih 39 orang dengan tidak mengkonsumsi air bersih 4 orang $(10,3 \%)$ dan mengkonsumsi air bersih 35 orang $(89,7 \%)$. Selanjutnya dari hasil analisa pada lampiran tabel uji chi-square antara kualitas air bersih dengan konsumsi air, diketahui bahwa nilai probabilitasnya $(0,000)<\operatorname{sig} \_\alpha=0,05$. Hasil analisis ini memenuhi kriteria persyaratan hipotesis ada hubungan, sehingga dapat disimpulkan bahwa kualitas air bersih mempunyai hubungan yang signifikan terhadap konsumsi air.

Dari 98 responden yang tidak ada sumber air lain 60 orang dengan tidak mengkonsumsi air bersih 44 orang $(73,3 \%)$ dan yang mengkonsumsi air bersih 16 orang $(26,7 \%)$ sedangkan yang memiliki suber air bersih lain 38 orang dengan tidak mengkonsumsi air bersih 19 orang (50\%) dan mengkonsumsi air bersih 19 orang (50\%).

Selanjutnya dari hasil analisa pada lampiran tabel uji chi-square antara kepemilikan sumber air bersih lain dengan konsumsi air, diketahui bahwa nilai probabilitasnya $(0,019)<\operatorname{sig} \_\alpha=0,05$. Hasil analisis ini memenuhi kriteria persyaratan hipotesis ada hubungan, sehingga dapat disimpulkan bahwa kepemilikan sumber air bersih lain mempunyai hubungan yang signifikan terhadap konsumsi air.

\section{Analisis Multivariat}

Metode pengolahan variabel dalam jumlah yang banyak, dimana tujuannya adalah untuk mencari pengaruh variabel-variabel tersebut terhadap suatu obyek secara simultan atau serentak. Uji statistik multivarit digunakan untuk menguji hubungan simultan lebih 
dari dua variabel. Sama seperti statistik univariat, statistik multivariat juga dapat dibedakan manjadi uji parametric dan nonparametrik. Dalam statistik multivariat, analisis dapat dibedakan menjadi analisis dependensi dan interpendensi. Dependensi berarti terdapat variabel bebas dan tidak bebas, sedangkan interpedensi tidak terdapat perbedaan antara dua variabel. Terdapat banyak model dan uji statistik multivariate berdasarkan dependensi dan interpendensi variabel, diantaranya regresi linier berganda, regresi logistic, analisis faktor dan cluster. Multidimensional scaling dan correspondence analisis.

Adapun syarat variabel $\mathrm{x}$ agar dapat dilanjutkan kepada analisis multivariate harus memiliki nilai $\mathrm{p}$-value $(\mathrm{sig})<\alpha \quad 0,25$. Ini berarti meskipun suatu variabel saat di uji menggunakan chi-square memiliki nilai $\mathrm{p}$-value $>0,05$, namun masih dibawah $<0,25$ tetap dapat dimasukkan dalam analisis multivariat.

Analisis multivariat dalam penelitian ini menggunakan uji regresi logistic berganda yaitu salah satu pendekatan model matematis untuk menganalisis pengaruh beberapa variabel independen terhadap variabel dependen kategorik yang bersifat dikotom atau binary. Variabel yang dimasukkan dalam model prediksi regresi logistic adalah variabel yang mempunyai nilai $\mathrm{p}<0,25$ pada analisis bivariatnya. Berdasarkan analisis bivariat diketahui dari keempat variabel independen (pendapatan keluarga, jumlah anggota keluarga, kualitas air bersih dan kepemilikan sumber air bersih lainnya), bahwa ada empat variabel yang mempunyai nilai $\mathrm{p}<0,25$ yaitu pendapatan keluarga, kualitas air bersih dan kepemilikan sumber air bersih lainnya sehingga variabel tersebut menjadi kandidat permodelan multivariat.

Pada analisis ini, penulis menggunakan analisis Regresi Logistic Metode Enter. Metode enter yaitu cara memasukkan semua variabel bebas kedalam model secara bersamaan untuk menentukan variabel bebas yang berpengaruh dan menentukan nilai Exp (B) atau dikenal dengan Odd Ratio (probability). Alasan peneliti menggunakan metode enter karena dapat mensleksi variabel bebas yang terbaik untuk tetap berada dalam model di mana merupakan sekumpulan variabel bebas yang dapat memberikan prediksi terbaik. Sehingga dalam prosesnya pada aplikasi SPSS, variabel dimasukkan dan dikeluarkan secara satu persatu dan bergantian. Namun proses tersebut dapat dijalankan secara otomotasi oleh aplikasi SPSS.

Pada penelitian ini, regresi logistic ganda diperoleh bahwa dari ke empat variabel independent diperoleh nilai $\mathrm{p}$ lebih kecil dari 0,05 yaitu $\mathrm{X} 1$ atau pendapatan keluarga mempunyai nilai signifikan 0,029<0,05 sehingga menerima $\mathrm{Ha}$ atau yang berarti pendapatan keluarga memberi pengaruh terhadap konsumsi air, X2 atau jumlah anggota keluarga mempunyai nilai signifikan $0,019<0,05$ sehingga menerima Ha atau yang berarti jumlah anggota keluarga memberi pengaruh terhadap konsumsi air, X3 atau jumlah kualitas air bersih mempunyai nilai signifikan $0,000<0,05$ sehingga menerima $\mathrm{Ha}$ atau yang berarti kualitas air bersih memberi pengaruh terhadap konsumsi air, X4 atau sumber air besih lain mempunyai nilai signifikan 0,019<0,05 sehingga menerima Ha atau yang berarti k sumber air bersih lain pengaruh terhadap konsumsi air.

Jika dilihat dari 4 variabel bebas tersebut, variabel kualitas air bersih memberi nilai pengaruh yang lebih besar. Hal ini ditunjukkan oleh nilai EXP (B) atau disebut juga OODS RATIO (OR). Variabel kulitas air bersih dengan nilai OR 1,362 maka orang yang tidak memiliki kualitas air bersih lebih beresiko mengkonsumsi air kotor 1,362 kali 
dibandingkan orang yang memiliki kualitas air bersih. Hasil uji regresi logistic berganda diperoleh nilai Overall percentage $=64,3 \%$ yang artinya faktor kualitas air bersih memengaruhi konsumsi air sebesar 64,3\% sisanya 35,7\% dipengaruhi oleh faktor lain.

Tabel 4. Variables in the Equation

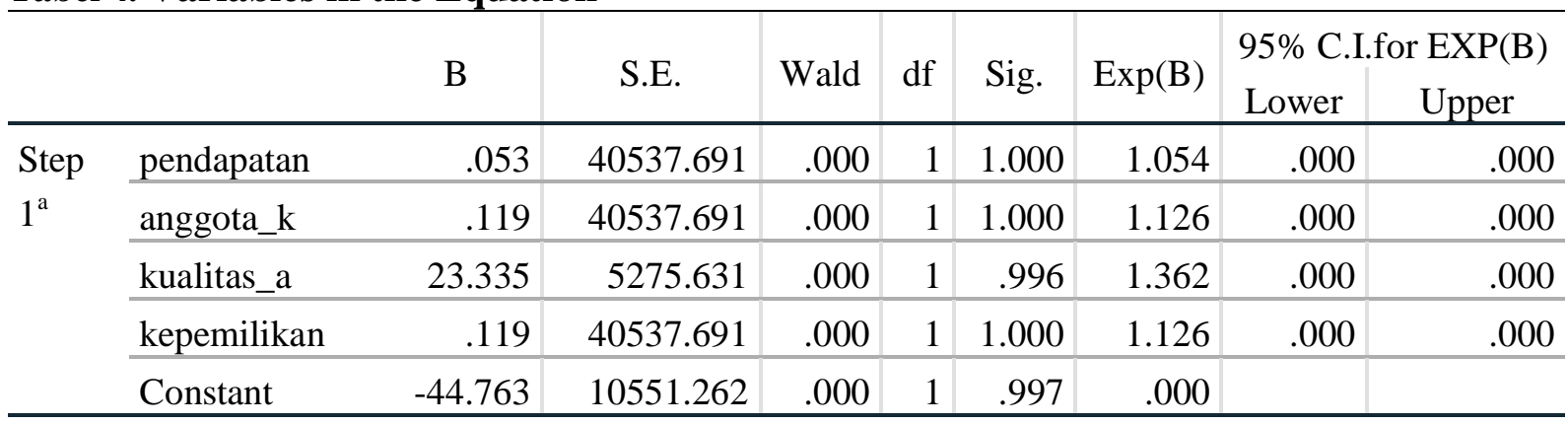

a. Variable(s) entered on step 1: Pendapatan, Anggota_K, Kualitas_A, Kepemilikan

*Dari uji logistic regression

\section{PEMBAHASAN}

\section{Penerapan Pengelolaan Konsumsi Air Bersih}

Kebutuhan air saat ini semakin meningkat sejalan dengan meningkatnya pertumbuhan penduduk dan pertumbuhan kota. Penyediaan kebutuhan air minum yang terus meningkat harus dipenuhi oleh Pemerintah. Ketersediaan air minum merupakan salah satu penentu peningkatan kesejahteraan masyarakat, yang mana diharapkan dengan ketersediaan air minum dapat meningkatkan derajat kesehatan masyarakat, dan dapat mendorong peningkatan produktivitas masyarakat, sehingga dapat terjadi peningkatan pertumbuhan ekonomi masyarakat. Oleh karena itu, penyediaan sarana dan prasarana air minum menjadi salah satu kunci dalam pengembangan ekonomi wilayah.

Kewajiban untuk mengembangkan penerapan pengelolaan konsumsi air bersih pada dasarnya merupakan tanggung jawab pemerintah kabupaten/kota. Kondisi saat ini masih banyak sistem air minum yang telah terbangun tetapi belum dimanfaatkan secara optimal terutama disebabkan karena belum dilaksanakannya komitmen investasi untuk pembangunan jaringan distribusi yang merupakan tanggung jawab daerah. Penerapan pengelolaan konsumsi air bersih pada rumah tangga dapat diartikan sebagai usaha secara sadar untuk memelihara dan atau memperbaiki mutu lingkungan agar kebutuhan dasar akan air minum dapat terpenuhi dengan baik. Pengelolaan lingkungan untuk sistem penyediaan air minum harus bersifat dinamis karena persepsi manusia untuk kebutuhan air minum berbeda-beda dan cenderung akan berubah dari waktu ke waktu. Dengan demikian, pilihan masyarakat untuk mendapatkan kebutuhan dasarnya tersebut menjadi prioritas dalam pembangunan.

Menilik permasalahan tumpang tindihnya program pengembangan sarana dan prasarana air minum memberi suatu pemikiran untuk menyelesaikan permasalahan tersebut secara sistemik, maka setiap rumah tangga disarankan untuk menerapkan pengelolaan konsumsi air bersih sesuai dengan kebutuhan sehingga dapat dilaksanakan secara optimal, menyeluruh, berkelanjutan dan terpadu. 
Zulhilmi, Idawati

\section{Hubungan pendapatan keluarga dengan konsumsi air}

Pada penelitian ini pendapatan keluarga berpengaruh terhadap konsumsi air. Hasil chi-square diperoleh nilai $p=0,029<0,05$. Maka dapat disimpulkan bahwa ada hubungan pendapatan keluarga dengan konsumsi air.

Hasil penelitian ini sejalan dengan penelitian Sefnat Kristianto Tomasoa. Yang berjudul analisis faktor yang mempengaruhi tingkat konsumsi air bersih PDAM di Kota Ambon. Berdasarkan hasil penelitian koefesien regresi tingkat pendapatan (X2) terhadap permintaan konsumsi air PDAM (Y) di Kota Ambon sebesar 0.588 dengan nilai t sebesar 11,038 dan signifikansi 0,000, dengan demikian t Hitung (11.038) > t tabel $(1,860)$, maka H0 ditolak dan Ha diterima. Ini menjelaskan bahwa variabel tingkat pendapatan (X2) memiliki pengaruh positif (searah) yang sangat signifikan terhadap peermintaan konsumsi air PDAM (Y) di Kota Ambon. Koefisien regresi tersebut menunjukan bahwa setiap kenaikan tingkat pendapatan (X2) sebesar 1 (satu) satuan, akan meningkatkan permintaan konsumsi air (Y) di Kota Ambon sebesar 0.588 satuan; sebaliknya setiap penurunan tingkat pendapatan keluarga (X2) sebesar 1 (satu) satuan, akan menurunkan permintaan konsumsi air (Y) di Kota Ambon sebesar 0.588 satuan, pada taraf signifikansi $=0,000$, dengan asumsi faktor-faktor lain yang mempengaruhi permintaan konsumsi air (Y) di Kota Ambon tetap konstan. Koefisien determinasi sebesar 0,842 mengindikasikan bahwa variabel tingkat pendapatan (X2) secara parsial menyumbang $84,02 \%$ terhadap variasi tinggi rendahnya permintaan komsumsi air PDAM (Y) di Kota Ambon, selebihnya $(26,08 \%)$ ditentukan oleh variabel lainnya. Dengan demikian, dapat disimpulkan bahwa semakin tinggi tingkat pendapatan keluarga akan menyebabkan permintaan komsumsi air di Kota Ambon juga cenderung semakin tinggi (Fatmah, 2010).

Selain itu, Hasil penelitian ini sejalan dengan penelitian Viola Carera yang berjudul Hubungan Antara Pendapatan Dengan Pola Konsums Masyarakat Nelayan di Desa Ketapang Kecamatan Padang Cermin Kabupaten Pesawaran. Berdasarkan hasil penelitian dapat kesimpulankan bahwa pendapatan mempengaruhi pola konsumsi masyarakat Desa Ketapang Kecamatan Padang Cermin Kabupaten Pesawaran, yang artinya bahwa semakin besar pendapatan masyarakat tersebut maka semakin besar pula konsumsi masyarakat tersebut. Pola konsumsi masyarakat nelayan desa arakan paling besar dialokasikan untuk pengeluaran konsumsi pangan sesudah itu untuk konsumsi non pangan (Departemen Kesehatan, 2007).

Kemudian hubungan konsumsi dengan pendapatan dijelaskan dalam teori Keynes yang menjelaskan bahwa konsumsi saat ini sangat dipengaruhi oleh pendapatan disposable saat ini. Jika pendapatn disposible tinggi maka konsumsi juga naik. Hanya saja peningkatan konsumsi tersebut tidak sebesar peningkatan pendapatan disposibel. Dengan perkataan lain bahwa peningkatan pendapatan suatu komunitas selalu diikuti bertambahnya tingkat konsumsi semakin tinggi pendapatan masyarakat secara keseluruhan maka makin tinggi pula tingkat konsumsi. Berarti jika penghasilan tinggi, maka masyarakat mampu mampu mengkonsumsi air bersih walaupun dengan pemasangan PDAM ataupun membeli air minum kemasan atau isi ulang (Friedman, Bowden, \& Jones, 2010).

Menurut asumsi peneliti, jika pendapatan responden mayoritas kurang dari Rp 2.500.000, hal ini dapat membuktikan bahwa pendapatan masyarakat di kecamatan 
peudada mayoritas rendah dan mempengaruhi pola komsumsi air. Pola konsumsi sering digunakan sebagai salah satu indikator untuk mengukur tingkat kesejahteraan. Dalam meningkatkan kesejahteraan hidup masyarakat dapat digambarkan melalui pendapatan nyata perkapita, sedangkan mutu kehidupan tercermin dari pengeluaran konsumsi dengan tujuan mempertahankan derajat hidup manusia secara wajar. Pendapatan perkapita merupakan rata-rata pendapatan untuk setiap individu. Individu-individu akan mempergunakan pendapatannya untuk menkonsumsi berbagai kebutuhan. Pada umumnya, kesejahteraan akan dicapai apabila seseorang dapat memenuhi kebutuhan diri sendiri dan keluarga dengan pendapatan yang dihasilkan. Tingkat kesejahteraan suatu masyarakat dapat pula dikatakan membaik apabila pendapatan meningkat dan sebagian pendapatan tersebut digunakan untuk mengkonsumsi hal-hal yang lebih urgen seperti air. Jika jumlah air terbatas dan kualitas air kurang, maka kebutuhan pokok adalah membeli air atau menggunakan PDAM dengan tariff pembayaran tertentu.

Pola konsumsi memberikan gambaran tingkat kemakmuran seseorang atau masyarakat. Adapun pengertian kemakmuran disini adalah semakin tinggi tingkat konsumsi seseorang maka semakin makmur, sebaliknya semakin rendah tingkat konsumsi seseorang berarti semakin miskin. Konsumsi secara umum diartikan sebagai penggunaan barang- barang dan jasa yang secara langsung akan memenuhi kebutuhan manusia. Untuk dapat mengkonsumsi, seseorang harus mempunyai pendapatan, besar kecilnya pendapatan seseorang sangat menentukan tingkat konsumsinya. Jika pendapatan responden tinggi, maka responden dapat menggunakan PDAM untuk kebutuhan air rumah tangga tanpa perlu melakukan pengelolaan air untuk dikonsumsi.

Fenomena yang terjadi ini membuat timbulnya usaha air minum isi ulang. Fenomena lain yang mendukung munculnya usaha air minum isi ulang adalah terjadinya peningkatan kebutuhan masyarakat sehingga masyarakat harus memiliki kemampuan untuk membeli air minum isi ulang. Jika pendapatan masyarakat meningkat, maka mereka akan mampu untuk membeli air isi ulang ini.. Air minum isi ulang tidak perlu di masak lagi karena sudah memiliki kualitas air yang layak untuk dikonsumsi. Akan tetapi, hal ini berbanding terbalik jika mayoritas penghasilan masyarakat rendah.

Pergeseran pola pengeluaran untuk konsumsi rumah tangga dapat dijadikan indikator penentuan kesejahteraan masyarakat, dengan anggapan bahwa membeli air adalah kebutuhan primer. Oleh karena itu motif konsumsi atau pola konsumsi suatu kelompok masyarakat sangat ditentukan pada pendapatan. Atau secara umum dapat dikatakan tingkat pendapatan yang berbeda-beda menyebabkan keanekaragaman taraf konsumsi suatu masyarakat atau individu. Namun, bila dilihat lebih jauh peningkatan pendapatan tersebut tentu mengubah pola konsumsi anggota masyarakat luas karena tingkat pendapatan yang bervariasi antar rumah tangga sesuai dengan tingkat kebutuhan dan kemampuan mengelolanya. Hal tersebut dapat disimpulkan bahwa, jika pendapatan masyarakat rendah, mereka tidak dapat membeli air untuk dikonsumsi, sehingga mereka harus membiasakan diri untuk mengolah air yang tidak layak di konsumsi menjadi air minum yang layak di konsumsi, sehingga dapat mengirit biaya belanja rumah tangga. 
Zulhilmi, Idawati

\section{Hubungan jumlah anggota keluarga dengan konsumsi air}

Pada penelitian ini jumlah anggota keluarga tidak berpengaruh terhadap konsumsi air. Hasil chi-square diperoleh nilai $p=0,292>0,05$. Maka dapat disimpulkan bahwa tidak ada hubungan jumlah anggota keluarga dengan konsumsi air.

Hasil penelitian Sefnat Kristianto Tomasoa menunjukkan bahwa variabel konsumsi air memiliki pengaruh terhadap jumlah anggota keluarga. Dengan demikian, dapat disimpulkan bahwa semakin kurangnya jumlah anggota keluarga akan menyebabkan permintaan/konsumsi air di Kota Ambon juga cenderung semakin turun.

Selain itu, Hasil penelitian ini sejalan dengan penelitian Fathia Rizky Ananda menyatakan bahwa jumlah seluruh anggota keluarga yang menjadi tanggungan dalam rumah tangga dapat memberikan indikasi beban rumah tangga. Semakin besar jumlah anggota keluarga berarti semakin banyak anggota keluarga yang pada akhirnya akan semakin berat beban rumah tangga untuk memenuhi kebutuhan sehari-harinya (Gamelia et al., 2015).

Menurut asumsi peneliti, berdasarkan data primer kecamatan Peudada memiliki jumlah penduduk 26.982 jiwa. Hal tersebut merupakan jumlah yang banyak. Sehingga besar kecilnya jumlah masyarakat ataupun jumlah anggota keluarga maka akan mempengaruhi pengeluaran konsumsi dalam suatu keluarga begitu pula kebutuhan air, setiap penambahan jumlah anggota rumah tangga maka kebutuhan terhadap air juga meningkat. Jika jumlah penyediaan air terbatas, maka keluarga wajib melakukan pengelolaan air pada rumahtangga.

\section{Hubungan kualitas air bersih dengan konsumsi air}

Pada penelitian ini kualitas air bersih berpengaruh terhadap konsumsi air. Hasil chi-square diperoleh nilai $p=0,000<0,05$. Maka dapat disimpulkan bahwa ada hubungan kualitas air bersih dengan konsumsi air.

Hasil penelitian ini sejalan dengan penelitian Henny Gusril, yang berjudul Studi Kualitas Air Minum Pdam Di Kota Duri Riau. Berdasarkan hasil penelitian untuk kondisi fisik cara penanggulangan dengan penyerapan bahan - bahan tertentu dengan cara menambahkan karbon aktif dengan cara penyaringan air melalui media yang terbuat dari karbon aktif kasar. Disarankan kepada pemerintah setempat untuk melalakukan penyuluhan tentang kualitas air yang layak konsumsi dan bersih kepada masyrakat setempat (Hardika, 2017).

Selain itu, hasil penelitian ini sejalan dengan penelitian Bondan Jati Kusumo Yang berjudul Pola Konsumsi Air Untuk Kebutuhan Domestik Pada Perusahaan Daerah Air Minum (Pdam) Di Kecamatan Manyaran Kabupaten Wonogiri. Berdasarkan hasil penelitian bahwa air yang layak sangat dibutuhkan memasak, mencuci, mandi, menyiram tanaman dilakukan hampir setiap hari. Kebutuhan manusia akan kebutuhan air selalu meningkat dari waktu ke waktu, bukan saja karena meningkatnya jumlah manusia yang memerlukan air tersebut, melainkan juga karena meningkatnya intensitas dan ragam dari kebutuhan akan air. Sama halnya di Kecamatan Manyaran yang mengalami perkembangan wilayah sehingga penggunaan air semakin tahun semakin tinggi. Wilayah yang berkembang akan menimbulkan meningkatnya aktivitas manusia yang membutuhkan sumber daya air dengan kualitas yang baik (Obstetri et al., 2017). 
Kebutuhan air dapat digolongkan menjadi tiga macam, yaitu kebutuhan air untuk rumah tangga (domestik), industri dan pertanian. Penggunaan air bersih yang paling menonjol adalah untuk rumah tangga karena kebutuhan seperti memasak, mencuci, mandi, menyiram tanaman dilakukan hampir setiap hari. Kebutuhan manusia akan kebutuhan air selalu meningkat dari waktu ke waktu, bukan saja karena meningkatnya jumlah manusia yang memerlukan air tersebut, melainkan juga karena meningkatnya intensitas dan ragam dari kebutuhan akan air, (M.D. Silalahi, 2002). Sama halnya di Kecamatan Manyaran yang mengalami perkembangan wilayah sehingga penggunaan air semakin tahun semakin tinggi. Wilayah yang berkembang akan menimbulkan meningkatnya aktivitas manusia yang membutuhkan sumber daya air.

Jika masyarakat tidak dapat mengelola konsumsi air bersih, maka selanjutnya selain PDAM, masyarakat juga banyak memanfaatkan air sumur untuk kebutuhan seharihari. PDAM merupakan perusahaan daerah sebagai sarana penyedia air bersih yang diawasi dan dimonitor oleh naparat- aparat eksekutif maupun legislatif daerah. Struktur tanah di daerah riau umumnya merupakan tanah organosol yang terbentuk dari bahan induk dimana didalamnya mengandung bahan organik dari hutan gambut dan tanah rawayang bersifat asam. Aliran sungai ranau berasal dari Rokan Hilir dan terus mengalir ke sungai bagan siapi-api. Aliran sungai Ranau bagian hilir dipenuhi oleh pemukiman penduduk, sedangkan bagian hulunya perkebunan sawit.

Untuk mengetahui kualitas air dinyatakan dengan beberapa parameter yaitu parameter fisika (suhu, kekeruhan, padatan terlarut), parameter kimia ( $\mathrm{PH}$, oksigen terlarut, BOD, kadar logam), parameter biologi (keberadaan plankton, bakteri dan sebagainya). Kualitas air mencakup keadaan fisik, kimia dan biologi yang dapat mempengaruhi ketersediaan air untuk kehidupan manusia, pertanian, industri, rekreasi dan pemanfaatan airlainnya. Syarat air bersih pemenuhan kebutuhan akan air bersih haruslah memenuhi dua syarat yaitu kuantitas dan kualitas (Notoatmodjo, 2012).

Namun patut disayangkan bahwa untuk memenuhi kebutuhan air sehari-hari yang semakin meningkat, keberadaan air bersih sangat dibutuhkan oleh masyarakat untuk mememnuhi kebutuhan sehari-hari. Keberadaan PDAM, seharusnya dapat membantu meringankan beban masyarakat. Dampak pertama yang mulai dirasakan dengan banyaknya masyarakat yang membeli air bersih dan menampung air hujan untuk kebutuhan air bersih. Sehingga dapat disimpulkan bahwa air PDAM adalah Perusahaan air minum yang dikelola oleh pemerintah yang bertujuan untuk memenuhi kebutuhan masyarakat secara perorangan untuk kebutuhan sehari-hari.

\section{Hubungan kepemilikan sumber air bersih lain dengan konsumsi air}

Pada penelitian ini kepemilikan sumber air bersih lain berpengaruh terhadap konsumsi air. Hasil chi-square diperoleh nilai $p=0,019<0,05$. Maka dapat disimpulkan ada hubungan kepemilikan sumber air bersih lain dengan konsumsi air.

Hasil penelitian ini sejalan dengan penelitian Rizqi Noor Fauziah, Yang berjudul Analisis Faktor-Faktor Yang Mempengaruhi Permintaan Air Pada Perusahaan Daerah Air Minum (PDAM) Di Daerah Istimewa Yogyakarta (DIY) Periode 2004-2013. Berdasarkan hasil penelitian jika air disekitar masyarakat bersih, maka akan meningkatkan jumlah 
pengunaan air, begitu pula sebaliknya, jika air disekitar tidak layak digunakan, maka masyarakat akan beralih menggunakan sumber air lainnya, seperti PDAM, sumur bor, air tadah hujan dan sebagainya.

Selain itu, Hasil penelitian ini sejalan dengan penelitian Syofyan, Z, Yang berjudul Analisa Ketersediaan Air Bersih untuk Kebutuhan Penduduk di Kecamatan Pauh Kota Padang. Setiap keluarga akan membutuhkan puluhan liter air bersih per hari untuk minum, membasuh mulut, mencuci, dan memasak, dan kebutuhan yang lain. Dalam sebulan akan dibutuhkan beribu-ribu liter air bersih untuk keperluan lain seperti mandi, mencuci pakaian dan perabotan rumah tangga. Untuk mengetahui besarnya potensi dan kebutuhan air serta keseimbangan air, kajian neraca air DAS Sungai Gayo dilakukan untuk memenuhi kebutuhan air domestik di Kecamatan Pauh. Ketersediaan air sungai dihitung berdasarkan debit andalan $80 \%$ yang didapat dari Sungai Gayo. Debit ini dijadikan dasar dalam menentukan ketersediaan air dalam DAS Sungai Gayo. Hal ini disimpulkan bahwa, selain sumber mata air, penduduk setempat mengunakan air sunggai sebagai sumber air bersih lainya (Muliati, Ismanto, \& Malara, 2014).

Menurut asumsi peneliti, air yang bersih merupakan tidak berasa, tidak berbau, tidak berwarna, dan tidak mengandung logam berat. Walaupun air dari sumber alam dapat diminum oleh manusia, terdapat risiko bahwa air ini telah tercemar oleh bakteri (misalnya Escherichia coli) atau zat-zat berbahaya. Walaupun bakteri dapat dibunuh dengan memasak air hingga $100{ }^{\circ} \mathrm{C}$, banyak zat berbahaya, terutama logam, tidak dapat dihilangkan dengan cara ini. Oleh karena itu, jika masyarakat tidak mempunyai sumber air bersih yang layak, mereka dapat menggunakan seperti air sungai, rata-rata lebih dari 40.000 kilometer kubik air segar diperoleh dari sungai-sungai di dunia. Ketersediaan ini (sepadan dengan lebih dari 7.000 meter kubik untuk setiap orang) sepintas terlihat cukup untuk menjamin persediaan yang cukup bagi setiap penduduk, tetapi kenyataannya air tersebut seringkali tersedia di tempat-tempat yang tidak tepat. Sebagai contoh air bersih di lembah sungai Amazon walupun ketersediaannya cukup, lokasinya membuat sumber air ini tidak ekonomis untuk mengekspor air ke tempat-tempat yang memerlukan.

Air tadah hujan, dalam pemanfaatan hujan sebagai sumber dari air bersih, individu perorangan/ berkelompok/ pemerintah biasanya membangun bendungan dan tandon air yang mahal untuk menyimpan air bersih di saat bulan-bulan musim kering dan untuk menekan kerusakan musibah banjir. Air permukaan merupakan air yang berada di permukaan bumi yang berasal dari air hujan yang jatuh ke permukaan bumi tetapi berada di permukaan tanah. Kualitas air ini biasanya tergantung daerah sekitarnya dimana air itu berada. Air permukaan kurang baik untuk langsung dikonsumsi oleh manusia, oleh karena itu perlu adanya pengolahan terlebih dahulu sebelum dimanfaatkan, air ini terdiri dari ; air sungai, telaga, danau, rawa dan sebagainya. Air bawah tanah adalah air yang berasal dari hujan yang jatuh ke permukaan bumi yang kemudia mengalami penyerapan ke dalam tanah dan mengalami proses filtrasi alamiah. Yang termasuk sumber air jenis ini terdiri dari air sumur dangkal, sumur dalam dan mata air.

Sumber-sumber air bersih ini biasanya terganggu akibat penggunaan dan penyalahgunaan sumber air seperti: Pertanian yaitu penghamburan air akibat ketiadaannya penyaluran air yang baik pada lahan yang diairi dengan irigasi (untuk penghematan dalam jangka pendek) dapat berakibat terjadinya kubangan dan penggaraman yang akhirnya 
dapat menyebabkan hilangnya produktivitas air dan tanah. Industri, walaupun industri menggunakan air jauh lebih sedikit dibandingkan dengan irigasi pertanian, namun penggunaan air oleh bidang industri mungkin membawa dampaknya yang lebih parah dipandang dari dua segi. Pertama, penggunaan air bagi industri sering tidak diatur dalam kebijakan sumber daya air nasional, maka cenderung berlebihan. Kedua, pembuangan limbah industri yang tidak diolah dapat menyebabkan pencemaran bagi air permukaan atau air bawah tanah, seihingga menjadi terlalu berbahaya untuk dikonsumsi. Air buangan industri sering dibuang langsung ke sungai dan saluran-saluran, mencemarinya, dan pada akhirnya juga mencemari lingkungan laut, atau kadang-kadang buangan tersebut dibiarkan saja meresap ke dalam sumber air tanah tanpa melalui proses pengolahan apapun. Kerusakan yang diakibatkan oleh buangan ini sudah melewati proporsi volumenya. Banyak bahan kimia modern begitu kuat sehingga sedikit kontaminasi saja sudah cukup membuat air dalam volume yang sangat besar tidak dapat digunakan untuk minum tanpa proses pengolahan khusus.

\section{KESIMPULAN}

Berdasarkan hasil dan pembahasan yang telah dipaparkan pada bab sebelumnya dapat diambil beberapa kesimpulan untuk penelitian ini yaitu:

1. Konsumsi air semakin meningkat seiring dengan meningkatnya pendapatan keluarga.

2. Semakin banyak jumlah anggota keluarga semakin meningkat kebutuhan akan air bersih.

3. Ada hubungan kepemilikan sumber air bersih lain dengan konsumsi air, dengan nilai probabilitasnya $(0,019)<$ sig_ $\alpha=0,05$

4. Variabel kualitas air bersih dominan memengaruhi penerapan pengelolaan konsumsi air bersih karena memiliki nilai EXP (B) yang lebih tinggi dari pada variabel yang lain. Hasil uji regresi logistic berganda diperoleh nilai Overall percentage $=64,3 \%$ yang artinya faktor kualitas air bersih memengaruhi konsumsi air sebesar 64,3\% sisanya $35,7 \%$ dipengaruhi oleh faktor lain..

\section{UCAPAN TERIMA KASIH}

Kepada pihak kecamatan peudada telah memberikan izin tempat dilakukannya penelitian ini.

\section{DAFTAR PUSTAKA}

Apriani, L. (2018). HUBUNGAN KARAKTERISTIK IBU, PELAKSANAAN KELUARGA SADAR GIZI (KADARZI) DAN PERILAKU HIDUP BERSIH SEHAT (PHBS) DENGAN KEJADIAN STUNTING (Studi kasus pada baduta 6-23 bulan di Wilayah Kerja Puskesmas Pucang Sawit Kota Surakarta). Jurnal Kesehatan Masyarakat (e-Journal), 6(4), 198-205.

Departemen Kesehatan, R. I. (2007). Pedoman operasional keluarga sadar gizi di desa siaga. Direktorat Bina Kesehatan Gizi Masyarakat. Jakarta: Depkes RI, 8-9.

Fatmah, F. (2010). Pengetahuan dan Praktek Keluarga Sadar Gizi Ibu Balita. Kesmas: 
Zulhilmi, Idawati

National Public Health Journal, 4(4), 162-171.

Friedman, M. M., Bowden, V. R., \& Jones, E. G. (2010). Buku ajar keperawatan keluarga: Riset, Teori dan Praktek. Jakarta: EGC, 5-6.

Gamelia, E., Sistiarani, C., Masfiah, S., Kesehatan, J., Fakultas, M., Universitas, I. K., \& Soedirman, J. (2015). Determinant of Mother' s Prenatal Care Behaviour, 109-114.

Hardika, M. D. (2017). HUBUNGAN PELAKSANAAN KELUARGA SADAR GIZI (KADARZI) DENGAN STATUS GIZI ANAK 1-4 TAHUN. Bidan Prada: Jurnal Publikasi Kebidanan Akbid YLPP Purwokerto.

Hariyadi, D., \& Ekayanti, I. (2012). Analisis pengaruh perilaku keluarga sadar gizi terhadap stunting di propinsi kalimantan barat. Teknologi Dan Kejuruan, 34(1).

Hartono, M., Sari, Y. S., Jannah, M., \& Anonim, T. (n.d.). RELATED KNOWLEDGE THIRD TRIMESTER PREGNANT WITH COMPLIANCE IN THE ANTENATAL CARE ( ANC ) IN HEALTH INSPECTION KUSUMABANGSA COMMUNITY HEALTH CENTERS.

Indonesia, K. K. R. (2014). InfoDATIN: Pusat Data dan Informasi Kementerian Kesehatan RI. Jakarta: Kementerian Kesehatan Republik Indonesia.

Karolina, E., Nasution, E., \& Aritonang, E. Y. (2013). HUBUNGAN PERILAKU KADARZI DENGAN STATUS GIZI BALITAUSIA 12-59 BULAN DI WILAYAH KERJA PUSKESMAS BLANGKEJEREN KECAMATAN BLANGKEJEREN KABUPATEN GAYO LUES TAHUN 2012. Gizi, Kesehatan Reproduksi Dan Epidemiologi, 2(2).

Kementerian Kesehatan, R. I. (2015). Infodatin pusat data dan informasi kementerian kesehatan RI. Situasi Gangguan Penglihatan Dan Kebutaan. Jakarta Selatan.

Liana, A. E., Soharno, S., \& Panjaitan, A. A. (2018). HUBUNGAN ANTARA PENGETAHUAN TENTANG GIZI SEIMBANG DENGAN INDEK MASA TUBUH PADA MAHASISWA. JURNAL KEBIDANAN, 7(2).

Moleong, L. J. (1999). Metodologi penelitian. Bandung: PT. Remaja Rosda Karya. Muhammad, I. (2013). Panduan Penyusunan Karya Tulis Ilmiah Bidang Kesehatan. Bandung: Cipta Pustaka Media Printis.

Muliati, D. D., Ismanto, A. Y., \& Malara, R. (2014). Hubungan Keluarga Sadar Gizi Dengan Status Gizi Balita Di Desa Mopuya Selatan Kecamatan Dumoga Utara Kabupaten Bolaang Mongondow. JURNAL KEPERAWATAN, 2(2).

Notoatmodjo, S. (2012). Promosi kesehatan dan perilaku kesehatan. Jakarta: Rineka Cipta, 45-62.

Obstetri, B., Kedokteran, F., Lampung, U., Ilmu, B., Keluarga, K., \& Kedokteran, F. (2017). Faktor-faktor yang Memengaruhi Kunjungan Antenatal Care ( ANC ) Ibu Hamil Factors Affecting The Antenatal Care ( ANC ) Visits on Pregnant Women, 7(November), 72-76.

Pelayanan, A., Care, A., Tamamaung, P., Makassar, K., \& Kunci, K. (n.d.). HAMIL PUSKESMAS TAMAMAUNG KOTA MAKASSAR Relationship of Antenatal Care Utilization to Pregnant Women at Tamamaung Health Center Makassar City Ayu Rahmayanti , Asiah Hamzah, Muhammad Yusran Amir PENDAHULUAN Dalam Undang-Undang No 36 Pasal 126 Tahun 2009 t, 1-10. 